Svetislava M. Bulajic ${ }^{*}$

doi: $10.5937 /$ spz63-23850

\title{
YET ANOTHER LOOK AT THE U.S. CONSTITUTIONALISM AND THE PHENOMENON OF 'WE THE PEOPLE'
}

\begin{abstract}
American constitutional scholars are unremittingly exploring their country's Constitution, as they are still deeply at odds on how the judges should seek out to discern the meaning of the solemn document. This article thus aspires to cast yet another look at the U.S. constitutionalism and constitutional theory of interpretation, so as to re-examine the institution of judicial law-making in our divisive political times, albeit not from the standpoint of 'hot' topics - one being the imminent impeachment procedure - but rather from the standpoint of the constitutional framework, its origin and legitimacy, most notably the Constitution' Preamble and its intrinsic 'We the People' phenomenon (People's Constitution for the People). Over the past years, these topics have enjoyed a major resurrection, primarily due to their association to a larger issue, namely fidelity to the law of the Constitution.

Keywords: American constitutionalism, constitutional historicism, constitutional interpretation, judicial law-making, 'We the People'.

\section{The historical approach to constitutionalism}

I say - and I say no longer with any doubt that a man may live greatly in the law...

Oliver Wendell Holmes Jr., $1886^{1}$

When we think of the U.S. constitutionalism and the origin of judicial law-making which indisputably accounts to enduring legitimacy of the U.S. constitution, we must necessarily think historically. As Robert W. Gordon has written, "history is not only a source of authority but of legitimacy." (Gordon, 1997, p. 1023) Some authors are even contending that the historicity of law is its single most prominent feature (in Kahn, 1999). These opinions are the major inspiration for the article before you, in which I am attempting to make more evident some of the ways we contemplate American constitutional history

${ }^{*}$ Master of Laws, PhD candidate at the Faculty of Law, University of Belgrade, Serbia e-mail: bulajic.svetislava@ gmail.com.

${ }^{1}$ From the talk given to the students of Harvard College.
\end{abstract}


and the present day constitutionalism. The central hypothesis of this article is the argument that our view of history determines our capability to understand the needs of the present. In other words, as the ultimate ambition is to bring together the historicity and present day constitutional legitimacy, 'We the People' of now are to be led by 'We the People' of then.

Constitutional historicists are infatuated with going back to the past for they see historical inquest as an objective and technical process, and because of their want for certainty they focus on authoritative documents and critical historical events. They insist that history conveys tradition and consent, and thus authority. Naturally, constitutional historicists are expected to explain this assertion in legal terms. They put forward that history can provide definite constitutional meanings for the present, and thereby lend both authority and restraint to constitutionalism and the scrupulous practice of judicial law-making (judicial review).

Historicism, as depicted above, holds an outstanding place in modern constitutional literature. Raoul Berger is one of most prominent contemporary proponents, as he debates almost entirely on historicist thread. A truly self-made originalist, he maintains that historical inquiry into constitutional interpretation can solve even the most complicated constitutional problems. In his own words, originalism is "not a scholastic exercise rooted in abstraction. It serves as a break on judicial revision of legislative enactments" (Berger, 1997, p. 526). Originalists claim that their mode of interpretation is superior to all others as it serves democracy the best. Robert H. Bork contends that "the original Constitution was devoted primarily to mechanisms of democratic choice" (Bork, 1984, p. 9), while former Attorney General Edwin Meese III in his famous speech to the American Bar Association reiterated: "A jurisprudence of original intention [...] reflects a deeply rooted commitment to the idea of democracy" (Meese, 1985, p. 9).

Another modality of historicism is textualism. Late Justice Antonin Scalia, an ostensible textualist, argues that history is objectively discernible and offers the finest interpretive techniques to give fixed meaning to constitutional text. He asserts that "for the vast majority of questions the historical answer is clear" (Scalia, 1989, p. 863), hence promoting the originalist interpretation into a chief limitation on judicial transgressions: "the main danger in judicial interpretation of the Constitution is that the judges will mistake their own predilections for the law...[O] riginalism does not aggravate the principal weakness of the system, for it establishes a historical criterion that is conceptually quite separate from the preference of the judge himself" (Scalia, 1989, p. 864).

One less popular form of originalist interpretation is traditionalism, which draws constitutional guidance from the tenets of tradition. ${ }^{2}$ These authors perceive tradition as a common consent on society's aspirations and values that ought to bind us to the present day. They see the adherence to tradition as an obligation to previous generations, and attribute to the past the paradigmatic authority. Traditionalists concentrate on major events and cultural heritage, thus perpetuating the preeminence of those who have inherited the privilege to determine and pass on the legacy and cultural ideals. ${ }^{3}$

\footnotetext{
${ }^{2}$ One of the most tenacious critiques of traditionalism comes from Jack Balkin's pen: "[t]he continuation of any tradition must necessarily kill off other possible lines of development, and relegate them to the margins or brand them as heretical" (see Balkin, 1997, p. 1715).

${ }^{3}$ For more information on traditionalism, see Brown, 1993, pp. 177-222.
} 
The most unpretentious variety of historicism admits that a bulk of historical questions surrounding American Constitution cannot be decisively answered, but assert that when they can, the answers should be granted the authority of present day. The principal hypothesis of so-called descriptivist argument is that "good history can accurately portray past reality" (Nelson, 1987, p. 1246).

So dominant is historicism in American constitutional thought that even the most vigorous opponents of historicism often resonate in the 'historical' registry. For instance, Cass R. Sunstein, professes himself a 'soft originalist' (Sunstein, 1995, p. 313), as he constantly entertains history in his constitutional interpretation, although from the stance of towering height of generality akin to Ronald Dworkin's or Justice Brennan's styles. Many constitutional historians admit that they choose to "emphasize all the ways in which the meaning of past practices depends upon the material conditions, symbolic system and tacit assumptions in which they were embedded" (Gordon, 1997, p. 1025). Perhaps the most exemplar of such argument is the infamous $\mathrm{H}$. Jefferson Powell's endeavor to 'out' the originalists by pointing that "original intentionalism was in fact a form of structural interpretation," and that "[t]o the extent that constitutionalist interpreters considered historical evidence to have any interpretive value, what they deemed relevant was evidence of the proceedings of the state ratifying conventions, not of the intent of the framers" (Powell, 1985, p. 888). That is also why this vein of argument is more adequately depicted as progressive, e.g. an understanding of past motivated by the narrative of progress of how one should relate to constitutional history. ${ }^{4}$

Historicism relies almost solely on the views of the Framers, and time and again put across, but seldom owns up, the supposition that the views of the Framers are central to defining the Constitution's meaning. Historicists repeatedly turn to the most prominent written documents, i.e. Madison's notes on Philadelphia Constitutional Convention and the Federalist Papers, wishing to sound as convincingly as possible, thus inevitably narrowing down already limited scope of their attention and via that upholding the mirage of sui generis authority. This immanent bias built into historical approach actually elevates historical arguments into not only effective but truly authoritative interpretative triumph. And that is why, irrespective of the said bias, we are to explore the captivating influence of historical approach to judicial law-making.

\section{The validity of (historical) judicial law-making}

Those of us to whom it is not given to 'live greatly in the law' are surely called upon to fail in the attempt.

Justice Oliver Wendell Holmes

This famous quote was not randomly picked, for the language used actually reveals " $t \mathrm{t}$ ]he voice of the veteran of the Civil War. Speaking to restless young man who had never known the challenge and adventure of any similar experience Holmes offered neither

\footnotetext{
${ }^{4}$ One the most analytical authors in this sense is Jack N. Rakove (see more in Rakove, 1996).
} 
argument nor authority, apart from his own. It was pure inspiration"...as further along he also used perennial wisdom to say "[w] hatsoever thy hand findeth to do, do it with thy might" (Wooten, 2008, p. 201). The enduring appeal of Holmes' legacy spanned the centuries, irrespective of his - in today's observers' eyes - questionable judicial choices, encompassing bad man's theory of the law and support to capital punishment. What is more important, for the purposes of present analysis, is that Holmes was the Justice who was interpreting the law with 'thy might': "I recognize without hesitation that judges do and must legislate." (S. Pac. Co. v. Jensen). A full century later, Holmes' voice simply echoed the ferociousness of his glorious predecessor's Chief Justice John Marshall dictum: "[I]t is a constitution we are expounding." (McCulloch v. Maryland).

Judicial law-making is a refined art and a dynamic process, depending on various factors that are not going to be explored here. What is going to be examined here is the very fact of judicial law-making existence ${ }^{5}$, and the primary concern of the entire legal academy: the propriety of such law-making. Or, in other words, how judges should (or shouldn't) execute their function in saying what the 'Law of the Land' is - not what it should be: "A judge who announces decision must be able to demonstrate that he began from recognized legal principles and reasoned in an intellectually coherent and politically neutral way to his result" (Bork, 1990, p. 2).

Under the keen scrutiny, constitutional scholars have ventured to identify and illuminate the constitutional principles that are steering the judicial law-making. In doing so, they departed from the Constitution itself, the document that Frank Michelman has labeled the ultimate 'law of lawmaking' (Michelman, 1998, p. 400). But, aware that not all of the limits on judicial law-making are explicitly expressed in the Constitution, these scholars relied almost solely on the views of the Framers, thus embracing the notion that Framers' intentions matter the most when it comes to discerning (construing) the true meaning of the Constitution. Admittedly, the scholars at case cross-referenced the Framer's intentions with a compilation of doctrines created by the judiciary via two centuries of judicial review, thereby crafting the self-explanatory syntagma 'Constitution of judicial law-making' (Greenawalt, 1975, p. 3596).

Addressing judicial law-making from the above described viewpoints has proven valuable indeed, as it confirmed that only 'constitutional principles' can determine whether the law-making judicial decisions are valid. Moreover, it allowed judges to forge their arguments more freely, as they opined on the foundation of established legal theories.

Historical approach to judicial law-making also permitted more profound understanding of judicial law-making practice, given that the established 'constitutional limits' imposed the fundamental precincts for valid judicial law-making function: judges will have unbounded law-making authority only when they are acting within the limits set forth by the "law of law-making.?

\footnotetext{
5 "Judges make law, and the public should know that they do" (Aharon, 2002, p. 62.).

${ }^{6}$ Leaning on Benjamin Cardozo (Cardozo, 1921).

${ }^{7}$ It is worth mentioning, although it is stricto sensu outside of the scope of this article, that Philip Bobbitt classified six modalities of acceptable 'constitutional' argument: historical, textual, structural, doctrinal, ethical, and prudential (Bobbitt, 1991, pp. 12-13).
} 
The constitutional approach to judicial law-making is normatively neutral regarding the content of 'judge-made constitution.' The constitutionalists recurrently disagree over the norms that are governing particular constitutional issues and, accordingly, over the principles that are limiting the extent of judicial law-making. Nonetheless, espousing constitutional perspective on judicial law-making puts forward an important indicator for evaluating jurisprudence and the judiciary's law-making role. This means that ensuing constitutional arguments are competing, allow for distinguishing valid from invalid judicial law-making, and, as a consequence, might even inspire judges to reconsider their approach to law-making responsibility.

Recommending ample solutions for every single aspect of the constitution that governs judicial law-making is far beyond the reach of any, let alone this article. Yet, one can still differentiate between constitutional principles, and those that are not constitutional by nature. That being said, one can therefore reasonably assume that such a distinction might instigate a more comprehensive debate about judicial law-making canons in an array of diverse constitutional contexts.

\section{Making sense of the Constitution's Preamble and the 'We the People' phenomenon}

We the people of the United States, in order to from a more perfect Union, establish Justice, insure domestic Tranquility, provide for the common defense, promote the general Welfare, and secure the Blessings of Liberty to ourselves and our Posterity, do ordain and establish this Constitution for the United States of America.

Philadelphia, 1787

(Library of Congress)

It was Governor Morris, perhaps the most eccentric of all Founding Fathers who coined the phrase 'We the People' and bestowed it on all the Americans of 'then' and 'now'. For, "[g]overnments are in fact... agents and trustees of the people..." (Madison, Federalist No. 46, in: Hamilton, Madison \& Jay, 2001).

The a-historic notion of 'We', which tantamount to paradigmatic 'We', actually conflates the identity of 'We the People Present' with the identity of 'We the People Past'. This was inevitable, as people are bound to the past so that they could understand the times in which they live in. People are born into history and language, as well as into the constitutional makeup not of their doing. The essential question thus becomes not why it is so, but who is to inhabit the power to uncover constitutional meaning, and how? This is how the public trust doctrine emerged.

As Justice Breyer methodically argued, the Constitution is to be interpreted in the light of a handful of its general purposes: "Its provisions form a simple coherent whole, permitting readers without technical knowledge to understand the document and the government it creates. And it traces the government's authority directly to a single source 
of legitimizing power - 'We the People' (Breyer, 2010, p. 1).

Justice Breyer actually advocates an approach to constitutional interpretation that applies enduring constitutional values to ever changing circumstances. Catherine A. MacKinnon, in connection to United States v. Morrison, ${ }^{8}$ illustrates this stance perfectly: "No woman had a voice in the design of the legal institutions that rule the social order under which women, as well as man, live" (MacKinnon, 1991, p. 1281). Her contention was that women were not the subject of constitutional design (equal protection clause of the Fourteenth Amendment), and that this exclusion fashioned the ensuing constitutional discourse in its entirety. ${ }^{9}$ Some of the Supreme Court's decisions hinge on the very same argument (United States v. Lopez and United States v. Morrison), whilst invoking a tremendously old jurisprudence (such as: Marbury v. Madison or A.L.A. Schechter Poultry v. United States.

Another illustrative instance of exemplary constitutional interpretation orbiting around history and public trust, comes from the province of the Fourteenth Amendment Due Process Clause jurisprudence, no matter how fierce are the criticisms of its modern application. Against such background, it is noteworthy to emphasize that "despite the nearly identical phrasing of the Fifth and Fourteenth Amendment Due Process Clauses, only the latter was originally understood to embrace a recognizable form of substantive due process" (Williams, 2012).

Contemporary substantive due process jurisprudence is an invention of the Warren and Burger Courts, having no remarkable antecedents in the Lochner era (Lochner v. New York). In his seminal dissent in Lochner, Justice Holmes rejected the majority's natural rights due process premises and any test that previously required courts to determine whether the legislation was arbitrary or unreasonable (Holmes, 1905, p. 75). Holmes' dissent eventually overturned Lochner and instilled the thirty years long pursuit for a new theory of due process protection. Henceforth, the Court became increasingly liberal, which prompted Justices to anchor their due process decisions in the notion of liberty and produced landmark activist cases such as Griswold v. Connecticut and Roe v. Wade.

Irrespective of the differing interpretations of the Due Process Clause' original meaning, the historical evidence remains to be strong. Unfortunately, this thought attracted sizably little attention in both legal scholarship and judiciary. The absence of this attention, however, cannot prevent a fair and impartial inquest into the original meaning of due process. It is likely no coincidence that the eminent contemporary critics of Lochner era failed to detect historic support for substantive due process, as it is no coincidence either that more current critics of post-Lochner era substantive due process decisions have tended to endorse the very conclusions of the Lochner era critics.

Most of the constitutional scholarship supports the existing state of affairs on the basis of non-originalist arguments. Admittedly, the debate is conducive to winner-takesit-all style argument, as there is a lot at stake ideologically speaking. In the light of so

\footnotetext{
${ }^{8}$ Where the Supreme Court partially annulled the Violence against Women Act (VAWA).

${ }^{9}$ The majority opinion derived its authority from the sources that were devised much ahead of the enfranchisement of women as a class. For more information on how women are excluded from the original (constitutional) contract and incorporated into new contractual order, see Patenam, 1998, p. 276.
} 
incremental evolution of due process concept, the framers from 1868 positively failed to recognize the inconsistency of their own understanding of due process and the one that was prevalent in 1791: "[ $\mathrm{t}$ ] his failure of intergenerational constitutional communication, though regrettable, does not justify a departure from the traditional default rule that identifies the original semantic meaning of a provision with its meaning at the time of enactment...[A]pplying this default rule...yields a simple and straightforward conclusion: the original meaning of one, and only one, of the Constitution's two Due Process Clauses - the Fourteenth Amendment Due Process Clause - encompasses a recognizable form of substantive due process." (Williams, 2010, p. 508)

At the very end, and to spice it up even more ${ }^{10}$, a brief consideration of the impeachment proceedings history appears to be worthy of attention after all. Impeachment was devised as an indispensable punitive action "against the incapacity, negligence or perfidy of the chief Magistrate" (Madison, 1787), for as Cicero wrote "they who administer the government should be like the laws which are led to inflict punishment not by wrath but by justice" (Cicero, De Offices) $)^{11}$. And, further along, "[it is] peculiarly the place of a magistrate to bear in mind that he represents the state and that it is his duty uphold its honor and its dignity, to enforce the law, to dispense to all their constitutional rights, and to remember that all this has been committed to him as a sacred trust". (Cicero, De Offices).

Governor Morris who was doubtful about the necessity of impeachment clause, eventually succumbed to Madison's argument, underscored by Hamilton who brought into play the public trust argument. In ensuing dealings, the Impeachment and Removal from Office Clause was largely supported by the public trust doctrine. Public trust argument was in fact used to resolve a hoary disagreement over whether an impeachable offence ("Misdemeanor") must constitute a violation of criminal law. Reverting to the public trust argument, Madison enumerated impeachable offences, including those coming outside of the criminal law. Some contemporary authors are doing pretty much the same (see Ackerman, 2019).

\section{Concluding remarks}

"I am not so naive (nor do I think our forebears were) as to be unaware that judges in a real sense 'make' law." (James B. Beam Distilling Co. v. Georgia, Scalia, L., concurring). It is with these words that I am opening the concluding remarks, as I am not about to hide behind the reality of judicial law-making.

To propose comprehensive account of any constitutional theory of interpretation is a pretty hefty task, well beyond the scope of any single article. This is especially true when the theory purports to defend the historical argument, given the extensiveness of its sources and the abundance of relevant literature and jurisprudence. When the attempt

\footnotetext{
${ }^{10}$ Through a fresh insight into the Founding Fathers' acts of constitutional statesmanship regarding similar challenges to those confronting populist leaders of the present day, including President Trump, see more in Ackerman, 2019 (last Chapter).

${ }^{11}$ Sporadically cited in the newspapers during the ratification debates.
} 
is coupled with an ambition to tie such a theory to some normative claims, like popular sovereignty, popular consent or the authority of the Constitution, the task becomes almost insurmountable. Most of the said claims are highly over-theorized and complex by nature, so to dare proposing solutions is a heavy-duty endeavor indeed.

Nonetheless, the effort employed is never futile, insofar as it aspires to also acknowledge the constitutional legacy that will necessarily shape the understanding of future constitutional struggles. As we search for guidance on the great constitutional issues of our own time, it is the constitutional accountability that we may never overlook. For, " $[t]$ he constitutional accountability stems from the foundational constitutional concept that the power of government flows from the people through the Constitution...[a]ccodingly, accountability to the people is an ineluctable component of any exercise of...power" (Brown, 2013, p. 1403).

\section{References}

Ackerman, B. 2019. Revolutionary Constitutions: Charismatic Leadership and the Rule of Law. Belknap Press, Harvard University Press.

Aharon, B. 2002. Foreword: a Judge on Judging: The Role of the Supreme Court in a Democracy. Harvard Law Review, Faculty Scholarship Series, 116(16), pp. 19-162. Balkin, J. 1997. Agreements with Hell and Other Objects of Our Faith. Fordham Law Review, 65, pp. 1703-1738.

Berger, R. 1997. Reflections on Constitutional Interpretation. BYU Law Review, 3, pp. $517-$ 536.

Bobbitt, P. 1991. Constitutional Interpretation. New Jersey: Blackwell Publishing.

Bork, R. 1984. Tradition and Morality in Constitutional Law. Washington, DC: American Enterprise Institute Press.

Bork, R. 1990. The Tempting of America: The Political Seduction of the Law. New York.

Breyer, S. 2010. Making Our Democracy Work: A Judge's View. New York: Vintage.

Brown, K. 2013. "We The People", Constitutional Accountability, and Outsourcing Government. Indiana Law Journal, 88(4), pp.1347-1403.

Brown, R. 1993. Tradition and Insight. Yale Law Journal, 103, pp. 177-222.

Cardozo, B. 1921. The Nature of the Judicial Process. New Haven: Yale University Press.

Cicero, De Offices.

Gordon, R. 1997. Foreword: On the critical Use of History: The Arrival of Critical Historicism. Stanford Law Revue, 49(5), pp.1023-1029.

Greenawalt, K. 1975. Discretion and Judicial Decision: The Elusive Quest for the Fetters that Bind Judges. Columbia Law Review, 75(2), pp.359-399.

Hamilton, A., Madison J., \& Jay J. 2001. The Federalist (The Gideon edition). George W. Carey \& James McClellan (eds). Indianapolis: Liberty Fund.

Kahn, P. 1999. The Cultural Study of Law: Reconstructing Legal Scholarship. Chicago: The University of Chicago Press, pp. xiv-432. 
MacKinnon, C. 1991. Reflections on Sex Equality Under Law. Yale Law Journal, 10(5), Centennial Issue, 1281, pp.1281-1328.

Meese, E. 1986. Speech to the American Bar Association, Washington D.C. (held on July 9, 1985), in The Great Debate: Interpreting Our Written Constitution 9 (Federal Society ed.).

Michelman, F. 1998. Brennan and Democracy: The 1996-1997 Brennan Center Symposium Lecture. California Law Review, 86, pp. 399-529.

Nelson, W. 1987. History and Neutrality in Constitutional Adjudication. Virginia Law Review, 72 p. 1246.

Patenam, C. 1998. The Sexual Contract. Palo Alto: Stanford University Press.

Powell, H.J. 1985. The Original Understanding of Original Intent. Harvard Law Review, 98(5), pp. 885-948.

Rakove, J. 1996. Original Meanings: Politics and Ideas in the Making of the Constitution, New York: Alfred A. Knopf ed.

Scalia, A. 1989. Originalism: The Lesser Evil. University of Cincinnati Law Review, 57 pp. 849-865.

Sunstein, C. 1995. Five Thesis of Originalism. Harvard Journal of Law and Public Policy, 19, pp. 311-315.

Williams, R. 2010. The One and Only Substantive Due Process Clause. Yale Law Journal, 120(3), pp. 408-516.

Wooten, H. 2008. Speech: Living in the Law. University of New South Wales Law Journal, 32(1), pp. 198-201.

\section{Web site references}

Williams R. 2012. Substantive Due Process in Historical Context, Cato Unbound, A Journal of debate. Available at: https://www.cato-unbound.org/2012/02/10/ryan-williams/ substantive-due-process-historical-context, last visited 28 October 2019.

Madison, J. 1787. Madison's Notes of Debates of the Federal Convention of 1787, in: John C. Payne's Copy of James Madison's Original Notes on Debates in the Federal Convention of 1787 (Manuscript Division, Library of Congress). Available at: https://www.loc.gov/resource/mjm.28_0270_1617/, last visited 28 October 2019.

\section{Case law}

A.L.A. Schechter Poultry v. United States, 295 U.S. 495 (1935).

James B. Beam Distilling Co. v. Georgia, 501 U.S. 529, 549 (1991), Scalia, L., concurring.

Lochner v. New York, 198 U.S.45 (1905).

Marbury v. Madison, 5 U.S. (1 Cranch) 137 (1803).

McCulloch v. Maryland, 17. U.S. 316, 407 (1819).

S. Pac. Co. v. Jensen, 244 U.S. 205, 221 (1917), Holmes, J., dissenting.

United States v. Lopez, 514. U.S. 549 (1995).

United States v. Morrison 529 U.S. 598 (2000). 


\section{Mr Svetislava M. Bulajić}

Doktorand na Pravnom fakultetu Univerziteta u Beogradu, Srbija

e-mail: bulajic.svetislava@gmail.com

\section{JOŠ JEDAN POGLED NA AMERIČKI KONSTITUCIONALIZAM I FENOMEN 'WE THE PEOPLE'}

\section{Sažetak}

Predmet ovog članka jeste analiza američkog konstitucionalizma, a u svetlosti istorijskog argumenta u ustavnoj interpretaciji i fenomena legitimizacije američkog Ustava posredstvom čuvene sintagme 'We the People' zabeležene u njegovoj preambuli. Članak tretira osobenosti istorijske teorije tumačenja ustava, imajući aspiraciju da čitaocu približi ovu školu mišljenja, pokuša da objasni njene pretpostavke i varijetete, sve braneći njene zaključke. Kako istoricizam u američkoj pravnoj književnosti odskora iznova pobuđuje pažnju američke doktrine, u samo središte debate nužno stavlja ne samo raspravu o adekvatnom metodu ustavne interpretacije, već i pitanje adekvatnosti i legitimiteta najdragocenije američke pravne ustanove - ustanove kontrole ustavnosti (judicial review). Pristalice istoricizma, naime, insistiraju na iznalaženju značenja i smisla ustava u samom tekstu ustava i njegovim izvorima, tzv. "originalnoj nameri" američkih očeva osnivača. Time zapravo podižu pravno-teorijski i politički ulog svake ustavne debate u SAD, a izazivajući dominirajuću američku misao o superiornosti suda - jedinom autoritetu vlasnom da tumačenjem fundamentalnih principa ustava otklanja slabosti i tenzije demokratskog političkog procesa.

Ključne reči: američki konstitucionalizam, ustavni istoricizam, tumačenje ustava, sudsko stvaranje prava, 'We the People' fenomen. 